by learning Bohemian, and so become missionaries at home in this city, or go as missionaries to the land of John Huss, the first reformer.

One word more,- -some young people act as if they thought modesty were not a virtue. Let such read the discourse of Dr. Chalmers, on the modesty of science, and learn what a grace modesty is in learning to do good. Modesty and piety, my young friends, will carry you anywhere in your work of well-doing. And may God give you these graces, and success in all your benevolent undertakings.

Iowa City, Jan. 6, 1869.

\title{
ORIGIN AND SIGNIFICATION OF THE NAME DES MOINES.
}

The following correspondence as to the name of Des Moines, is given with respect to the various views which are entertained:

DaVENPORT, March 11, 1858.

Rev. S. Storrs Howe: - I hunted up my old friend, "Father" Pelemarques, who informs me the correct writing of the river is Des Moines -meaning "of the Monks;" that is, the River of Monks. He says he once met an old Frenchman, who had seen the remains or ruins of the convent. . . The river, therefore, was the River Des Moines, or "River of the Monks."

Yours truly,

H. Y. Slaymaker.

Reo. S. S. Honoe, Des Moines, Ioroa,-

DAVENPoRT, March 11, 1858.

Dear Sir:- I received your note this morning, in regard to the definition of "Des Moines." The name was given by the Indians; that is, the Indians living this side of the river were a large tribe, and those on the other side were few in number, and had there the name of Des Moines, meaning the small tribe of Indians. As regards some persons saying it was derived from the Monks, that is incorrect.

Respectfully yours,

Antoine LeClatre.

Of course, the editor and the public must concede to $\mathrm{Mr}$. Le Claire the true explanation and signification to be "De Moins," or "De Moine," that is "the less" tribe, and so transferred to the river, and from it to the city of De Moin, as it may well be spelled, leaving off the hissing letter " $s$," as the French do not sound it. 
Copyright of Annals of Iowa is the property of State of Iowa, by \& through the State Historical Society of Iowa and its content may not be copied or emailed to multiple sites or posted to a listserv without the copyright holder's express written permission. However, users may print, download, or email articles for individual use. 